\title{
Effect of Ethanolic Extract of Icacinia manni Tuber on the Reproductive Parameters of Male Rats
}

\author{
Udokang Nsikak Ephraim ${ }^{1, *}$, Udom Utibe Godwin ${ }^{1}$, Osim Eme Efiom ${ }^{2}$, Antai Atim Bassey ${ }^{2}$ \\ ${ }^{1}$ Department of Physiology, University of Uyo, Uyo, Nigeria \\ ${ }^{2}$ Department of Physiology, University of Calabar, Calabar, Nigeria
}

Email address:

nsikakudokang@yahoo.com (U. N. Ephraim)

${ }^{*}$ Corresponding author

\section{To cite this article:}

Udokang Nsikak Ephraim, Udom Utibe Godwin, Osim Eme Efiom, Antai Atim Bassey. Effect of Ethanolic Extract of Icacinia manni Tuber on the Reproductive Parameters of Male Rats. American Journal of Health Research. Vol. 7, No. 5, 2019, pp. 89-99.

doi: 10.11648/j.ajhr.20190705.16

Received: September 10, 2019; Accepted: September 28, 2019; Published: October 20, 2019

\begin{abstract}
The shift from the current energy sources in foods and feeds to a more available and affordable sources have been observed in recent times. This is in an attempt to balance food availability and utilization in the increasing population. A search for an appropriate and a less expensive energy source in poultry feeds has driven poultry farmers to research on Icacinia manni. This plant is widely available mostly in the tropical rain forest in Africa as a wild shrub with large underground tubers of high carbohydrate content. This study was carried out on male rats with Icacinia manni tuber, a product that has been observed to supplement other energy sources in foods and feeds. This research work examined the effects of crude ethanolic extract of Icacinia manni tuber on Sex hormonal levels, Seminalysis and Testicular histology of albino Wistar rats. A total of 40 rats divided into four groups (A, B, C and D) of ten rats each were used for this study. The Icaciania manni tuber was extracted using ethanol. The median lethal dose $\left(\operatorname{LD}_{50}\right)$ of $894.43 \mathrm{mg} / \mathrm{kg}$ of the extract was estimated using albino Wistar mice by intra peritoneal (Ip) route using the method of Larke (1983). Group A served as the control and was treated with distilled water at $5 \mathrm{ml} / \mathrm{kg}$. Group B, C and D were the experimental (treated) groups gavaged with $1 / 10,2 / 10$ and $3 / 10$ of $\mathrm{LD}_{50}$ respectively for 28 days. On the $28^{\text {th }}$ day, the animals were anaesthetized with chloroform and sacrificed. Blood samples were obtained by cardiac puncture, centrifuged and serum obtained for hormonal assay. Abdominal dissection was extended to recover the testis for histology and epididymis for seminalysis. The result revealed a highly significant $(\mathrm{p}>0.05)$ decrease in testosterone and progesterone levels in group D compared with the control. Apart from estradiol level which was not statistically affected, other hormone levels were increased $(p>0.05)$ in group D compared with the control group. The decrease in sperm concentration was also observed in the treated groups when compared with the control group. The sperm morphology showed severe damage on sperm especially at the neck and head region in the treated group compared to control group. Sperm motility was significantly reduced in the treated groups compared to control group. Histologically, damages to most part of the testis were observed in the treated groups compared to control group. This study finally projects that Icacinia manni tuber has deteriorating effect on male reproductive health.
\end{abstract}

Keywords: Icacinia manni tuber, Sperm Morphology, Sperm Motility, Sperm Concentration, Sex Hormones, Testicular Histology, Antifertility

\section{Introduction}

The world's population is on the increase. Suggestions regarding the possible reasons have been made. While some look at the improvement in the health sectors including advances in infertility management and other disease conditions leading to increase birth to death rate, others assume the economic position of increase income earnings.

Demographers have estimated that by the year 2050, the world will hit a population of about 9 billion. As a matter of fact, the effect of the increasing population will not only be on man, but on the ecosystem as a whole. As such, the 
balance between energy sources (specifically in the aspect of nutrition) and its consumption is being threatened. This becomes a driving force in search of a readily available and an affordable source of energy in food. Though Icacinia manni tuber has proven to be an alternative source of energy in foods and feeds, its effects on the body system is an area of concern to researchers.

Icacinia manni (Earth Ball, by direct interpretation of its vernacular name) is well known in Africa because of its unique ball-shaped underground tuber. It grows as a wild shrub in tropical rain forest. Icacinia manni tubers are mainly carbohydrates [1]. It also contains some anti-nutritional factors such as hydrogen cyanide, alkaloids, phytic acid, oxalic acid and tannins which limit its use as animal feed [2, 3]. A recent research by Essien and Sam now focuses on how to improve its use in animal feeds [4].

As energy source, Icacinia manni tuber has been supplemented in poultry feeds as a cheaper and readily available product. There have also been claims of its use to adulterate garri and even eaten as food in lean times. Antai and Nkwelang, wrote that it is suspected that the local garri producers mix Icacinia manni tuber with cassava paste in garri production [5]. Icacinia manni has a long term history in its use for medicinal purposes. Burkil, in 1985 had stated that Icacinina manni tuber can be used as remedy for gastrointestinal troubles and dysentery [6]. This tuber is also listed among medicinal plant used by Ehotile people of Côte d'Ivoire in the treatment of Dysmenorrhoea in the work by Melan et al. [7]. It has also been implicate in the treatment of boil and stroke.

Human exposure to Icacinia manni could be detrimental to health due to the presence of toxic chemicals. These detrimental effects could be by direct or indirect exposure as in consumption as food or for medical purposes or consumption of meat from animals fed with it. In this current study, the effect of ethanolic extract of Icacinia manni tuber on reproductive parameters in male rats is being accessed.

\subsection{Purpose of the Study}

To access the effect of ethanolic extract of Icacinia manni tuber in male rats using the following criteria;

i. Sex hormonal levels

ii. Seminalysis

iii. Testicular histology

\subsection{Significance of the Study}

It has been observed that directly or indirectly, human has been exposed to the toxic substances contained in Icacinia manni tubers. As such, this research seeks to find the immediate and possibly suggest the delayed effects of these toxins on reproductive health.

\section{Methodology}

\subsection{Collection, Identification of Icacinia manni}

Icacinia manni has two parts - The leafy shrub on the outside and the tuber underground. The plant with tuber, leaves and stem was harvested from the bush in Uyo, Akwa Ibom state of Nigeria and taken to Department of Botany, University of Uyo, Nigeria for identification. This research work made use of the tuber. The leaves and stem were discarded.

\subsection{Preparation and Extraction of Icacinia manni}

The tuber was washed with water to remove sand, cut into pieces and sun dried. The dried specimen was sent to department of pharmacognosy, University of Uyo, Nigeria for extraction with $80 \%$ Ethanol.

\subsubsection{Maceration}

After two (2) weeks of drying the tuber was reduced into powder. The powder was divided into two parts. One part was macerated in $80 \%$ ethanol for $72 \mathrm{hrs}$ to give the crude ethanolic extract. The other part was successively macerated for $72 \mathrm{hrs}$ in $\mathrm{n}$-hexane and ethanol to give the corresponding gradient fraction of these solvents. The liquid filtrate was concentrated and evaporated to dryness using rotary evaporator. The creamy liquid collected from the filtrate turned brownish and thick after concentration to dryness. The pure extract was stored in a refrigerator at $4{ }^{\circ} \mathrm{C}$ pending when it will be used for the proposed study.

\subsubsection{Preparation of Stock Concentration}

The stock solution was prepared using std procedures.

\subsection{Experimental Animals}

Four (4) weeks old male Wistar rats were used in the experiment. The rats were obtained from the animal house of the Department of Physiology, University of Calabar and kept in a well ventilated experimental section of the animal house of the faculty of Pharmacy, University of Uyo, Uyo.

The animals were fed and kept for 7 days to acclimatize before the experiment began. They were kept in wooden cages and fed with rat chow from vital feeds. They were allowed free access to drinking water throughout the experimental period.

\subsection{Determination of Median Lethal Dose $\left(L_{50}\right)$}

The median lethal dose $\left(\mathrm{LD}_{50}\right)$ of the extract was estimated using albino Wistar mice by intra peritoneal (ip) route using the method of Lorke (1983) [8].

\subsection{Experimental Procedures}

A total of forty (40) male rats weighing between 60 and $100 \mathrm{gm}$ were randomly assigned to four (4) groups.

Group A served as the control. Distilled water at $5 \mathrm{ml} / \mathrm{kg}$ was administered for 28 days. Group B, C and D had low, intermediate and high dose of extract.

Group B received $1 / 10$ of $\mathrm{LD}_{50}$ by feeding tube

i.e. $1 / 10 \times 894.43 \mathrm{mg} / \mathrm{kg}=89.44 \mathrm{mg} / \mathrm{kg}$

Group $\mathrm{C}$ received $2 / 10$ of $\mathrm{LD}_{50}$ by mouth through a 
feeding tube

i.e. $178.88 \mathrm{mg} / \mathrm{kg}$

Group D received $3 / 10$ of $\mathrm{LD}_{50}$ by mouth through a feeding tube

i.e. $268.32 \mathrm{mg} / \mathrm{kg}$

Stock concentration was $50 \mathrm{mg} / \mathrm{ml}$. Due to small variation in body weight of the animals, the average dose per group was used for all the animals in that group.

\subsection{Sample Collection}

On the twenty eight $\left(28^{\text {th }}\right)$ day, the animals final weight was taken. The animals were anaesthetized with chloroform. Blood samples were obtained by cardiac puncture. Serum obtained for biochemical analysis. Abdominal dissection was extended to recover the testis and epididymis. Approval was gotten from the Local Research Ethical Committee of the University of Uyo, Uyo, Akwa Ibom State, Nigeria.

\subsection{Analysis}

\subsubsection{Semen Analysis}

Epididymis was put in a Petri dish containing Normal Saline. It was teased with the aid of a needle to release sperm cells into the saline solution. With the aid of pipette $1 \mathrm{ml}$ at a time was taken for microscopy on a plain glass slice (sperm motility test) - Rouge, 2004 [9]. Sperm morphology test was done by staining air-dried and fixed smears with haematoxylin/eosin stain.

The Neubers' haemacytometer was used for sperm count (Zaneveld and Polakoski, 1977). [10]

\subsubsection{Biochemical Analysis}

The biochemical analysis of six (6) male reproductive hormones was done using the Enzyme Linked immunosorbent Assay (ELISA) method.

These hormones include:
a) Estradiol
b) Progesterone
c) Testosterone
d) Follicle - stimulating hormone (FSH)
e) Luteinizing hormone ( $\mathrm{LH})$
f) Prolactin

\subsubsection{Histological Analysis}

Testes were immediately immersed in Bouin's solution for fixation and processed until embedded in paraffin for histological analysis. Five micron thick sections were prepared using microtome (microTecLaborgerate $\mathrm{GmbH}$ Rudolf-Diesel-Straße, Walldorf, Germany) and stained using Hematoxylin and Eosin (H\&E) method. The specimens were examined under Olympus/3H light microscope-Japan.

\subsubsection{Statistical Analysis}

Data obtained were analyzed using Mean, Standard Error of Mean and Analysis of Variance followed by Duncan's test which was used to determine the direction of significance. The level of hormones and seminalysis were reported in the form mean \pm SEM and statistical significance was established at 0.05 level of significance with $\mathrm{p}<0.05$ signifying significance. Data were analyzed using the Statistical Package for Social Sciences (SPSS version 22.0) and GraphPad Prism 5.0.

\section{Results}

\subsection{Effect of the Ethanolic Extract of Icacinia manni on Hormones Levels}

\subsubsection{Effect on Hormonal Levels in the Different Groups}

The mean values of FSH, LH, Prolactin, Progesterone, Estradiol and Testosterone for male rats after 28 days of administration of ethanolic extract of Icacinia manni tuber, compared with control group, is shown in table 1. Levels of $\mathrm{FSH}$, was statistically high in group D compared with control. Lutheniniing hormone (LH) level was also statistically high in group D. Low and intermediate doses had no statistically significant difference in levels for FSH, LH and prolaction. Prolaction level was also high in group D. Progesterone levels were significantly depressed with extract administration, seen in low, intermediate and high doses. Testosterone levels were also depressed in a dose dependent fashion. Estradiol levels did not show statistically significant changes. Thus, administration of Icacinia manni tuber extract had a dose dependent depressive effect on the levels of progesterone and testosterone whereas elevated levels of FSH, LH and prolaction were noted in high doses. With low doses the effects were unchanged.

Table 1. Effect of Ethanolic Extract of Icacinia manni on Hormonal Levels in the different groups.

\begin{tabular}{|c|c|c|c|c|}
\hline PARAMETERS & GROUP A & GROUP B & GROUP C & GROUP D \\
\hline Follicle Stimulating Hormone (FSH) $(\mathrm{mm} / \mathrm{l})$ & $0.32 \pm 0.05$ & $0.32 \pm 0.06$ & $0.28 \pm 0.04$ & $0.37 \pm 0.0^{\text {** }}$ \\
\hline Luteinizing Hormone $(\mathrm{LH})(\mathrm{mm} / \mathrm{l})$ & $0.30 \pm 0.01$ & $0.37 \pm 0.19$ & $0.36 \pm 0.21$ & $0.38 \pm 0.02^{*}$ \\
\hline Prolactin (ng/ml) & $0.21 \pm 0.02$ & $0.24 \pm 0.05$ & $0.21 \pm 0.02$ & $0.24 \pm 0.02^{* *}$ \\
\hline Progesterone (ng/mg) & $6.6 \pm 3.58$ & $1.96 \pm 1.09^{*}$ & $3.29 \pm 2.44^{*}$ & $1.96 \pm 1.78^{*}$ \\
\hline Estradiol (ng/ml) & $2.14 \pm 1.13$ & $2.87 \pm 1.56$ & $2.05 \pm 2.00$ & $2.72 \pm 0.5$ \\
\hline Testosterone (ng/ml) & $2.96 \pm 2.55$ & $0.50 \pm 0.05^{*}$ & $0.35 \pm 0.17^{*}$ & $0.86 \pm 0.44^{* *}$ \\
\hline
\end{tabular}

Data are presented as mean $\pm \mathrm{SD} \mathrm{P}<0.05$ is considered significant

*Significantly different at $\mathrm{p}<0.05$ when compared with group A (control)

**Significantly different $\mathrm{p}<0.01$ when compared with group A (control) 


\subsubsection{Mean Hormone Profile for Male Untreated (MUT) and Male Treated (MT)}

Table 2. Effect of Ethanolic Extract of Icacinia manni on Hormonal Levels in Male Albino Wistar Rats in the treated and untreated groups.

\begin{tabular}{lll}
\hline Parameters & Untreated & Treated \\
\hline Follicle Stimulating Hormone $(\mathrm{FSH})(\mathrm{mm} / \mathrm{l})$ & $30.67 \pm 0.67^{\mathrm{a}}$ & $31.33 \pm 1.33^{\mathrm{a}}$ \\
Luteinizing Hormone $(\mathrm{LH})(\mathrm{mm} / \mathrm{l})$ & $19.33 \pm 0.67^{\mathrm{a}}$ & $17.67 \pm 1.45^{\mathrm{a}}$ \\
Prolactin $(\mathrm{ng} / \mathrm{ml})$ & $12.33 \pm 0.88^{\mathrm{a}}$ & $11.67 \pm 0.33^{\mathrm{a}}$ \\
Progesterone $(\mathrm{ng} / \mathrm{mg})$ & $2.88 \pm 0.93^{\mathrm{a}}$ & $2.50 \pm 1.76^{\mathrm{a}}$ \\
Estradiol $(\mathrm{ng} / \mathrm{ml})$ & $5.00 \pm 0.00^{\mathrm{a}}$ & $2.67 \pm 1.20^{\mathrm{a}}$ \\
Testosterone $(\mathrm{ng} / \mathrm{ml})$ & $25.83 \pm 5.07^{\mathrm{a}}$ & $6.00 \pm 1.61^{\mathrm{b}}$ \\
\hline
\end{tabular}

Values reported in the form mean \pm SD. Similar superscript letters mean not significantly different $(p>0.05)$ while different superscript letters mean significantly different $(\mathrm{p}<0.05)$.

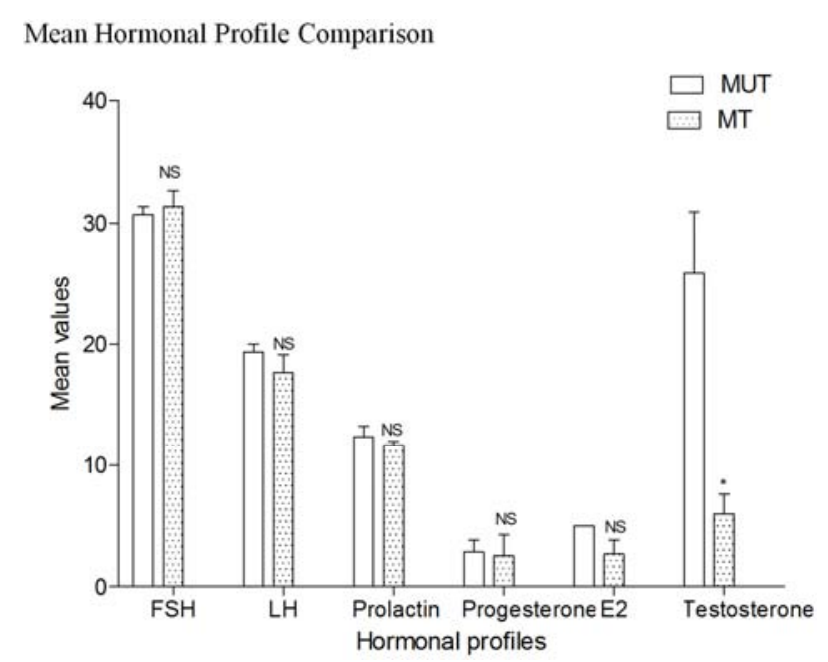

Figure 1. Graphical comparison of the Mean hormonal profile between Male Untreated (MUT) and Male Treated (MT).

\section{Key:}

MUT- Male Untreated group

MT- Male Treated group

NS $=$ not significantly different from MT at $5 \%(\mathrm{p}>0.05)$, *significantly

different from MT at $5 \%(\mathrm{p}<0.05)$

Follicle Stimulating Hormone (FSH)

The mean FSH obtained for male treated $(31.33 \pm 1.33)$ was not significantly higher than male untreated $(30.67 \pm 0.67)$ at
$5 \%(\mathrm{t}=0.447, \mathrm{p}=0.678, \mathrm{p}>0.05)$.

Luteinizing Hormone (LH)

The mean LH for Male untreated $(19.33 \pm 0.67)$ was not significantly different from that of male treated $(17.67 \pm 1.45)$ at $5 \%(\mathrm{t}=1.04, \mathrm{p}=0.356, \mathrm{p}>0.05)$.

Prolactin

The mean prolactin between Male Untreated $(12.33 \pm 0.88$ was not significantly different from Male treated $(11.67 \pm 0.33)$ at $5 \%(t=1.04, \mathrm{p}=0.519, \mathrm{p}>0.05)$.

Progesterone

The mean progesterone of $2.88 \pm 0.93$ and $2.50 \pm 1.76$ were obtained for Male untreated and Male treated respectively. There was no significantly difference in mean progesterone between the two group at $5 \%(\mathrm{t}=0.168, \mathrm{p}=875, \mathrm{p}>0.05)$, although, there was a marginal difference between the two groups.

\section{Estrogen}

The mean estrogen for Male Untreated and Male treated were obtained as follows $5.00 \pm 0.00$ and $2.67 \pm 1.20$. The mean estrogen for Male untreated was not significantly different from that of Male treated at $5 \%(\mathrm{t}=1,94, \mathrm{p}=0.124$, $\mathrm{p}>0.05)$.

Testosterone

The mean testosterone for male untreated $(25.83 \pm 5.07)$ was significantly higher than that of the male treated $(6.00 \pm 1.61)$ at $5 \%(t=3.73, p=0.02, p>0.05)$.

\subsection{Effect of the Ethanolic Extract of Icacinia manni on Semen Profile}

Table 3. Effect of Ethanolic Extract of Icacinia manni on Semen profile in the treated and untreated groups.

\begin{tabular}{|c|c|c|c|}
\hline Parameters & & Untreated & Treated \\
\hline \multirow{3}{*}{ Sperm motility } & FP & $71.67 \pm 4.41^{\mathrm{a}}$ & $55.00 \pm 2.89^{b}$ \\
\hline & SL & $16.67 \pm 3.33^{\mathrm{a}}$ & $21.67 \pm 2.08^{\mathrm{a}}$ \\
\hline & $\mathrm{IM}$ & $5.00 \pm 0.00^{\mathrm{a}}$ & $13.00 \pm 1.67^{b}$ \\
\hline \multirow{5}{*}{ Mean Sperm Morphology } & HD & $5.00 \pm 0.58^{\mathrm{a}}$ & $10.67 \pm 0.67^{b}$ \\
\hline & ND & $4.67 \pm 1.20^{\mathrm{a}}$ & $10.67 \pm 0.67^{\mathrm{b}}$ \\
\hline & MPD & $5.00 \pm 0.00^{\mathrm{a}}$ & $9.00 \pm 3.06^{\mathrm{a}}$ \\
\hline & $\mathrm{TD}$ & $4.00 \pm 0.58^{\mathrm{a}}$ & $6.67 \pm 1.45^{\mathrm{a}}$ \\
\hline & $\% \mathrm{NM}$ & $81.33 \pm 0.88^{\mathrm{a}}$ & $62.67 \pm 3.84^{b}$ \\
\hline \multirow{3}{*}{ Sperm Concentration } & UR & $16.00 \pm 0.58^{\mathrm{a}}$ & $13.33 \pm 1.76^{\mathrm{a}}$ \\
\hline & $\mathrm{UL}$ & $15.33 \pm 1.86^{\mathrm{a}}$ & $12.67 \pm 0.88^{\mathrm{a}}$ \\
\hline & LR & $20.67 \pm 0.88^{a}$ & $14.00 \pm 2.08^{b}$ \\
\hline
\end{tabular}




\begin{tabular}{llll}
\hline Parameters & & Untreated & Treated \\
\hline LL & $17.67 \pm 0.33^{\mathrm{a}}$ & $19.33 \pm 0.33^{\mathrm{b}}$ \\
& PER & $69.67 \pm 3.82^{\mathrm{a}}$ & $59.33 \pm 3.48^{\mathrm{a}}$ \\
& LD RATIO & $73.33 \pm 1.67^{\mathrm{a}}$ & $58.33 \pm 1.67^{\mathrm{b}}$ \\
\hline
\end{tabular}

Values reported in the form mean \pm SD. Similar superscript letters mean not significantly different $(p>0.05)$ while different superscript letters mean significantly different $(\mathrm{p}<0.05)$.

Keys

FP- Fast Progressive Sperm; SL- Slow Progressive Sperm; NP- None Progressive Sperm; IM- Immotile Sperm; HD- Head defect; ND- Neck defect; MDMid-piece defect; TD- Tail defect; \%NM- \% Normal Morphology; UR- Upper Right Counting Chamber; UL- Upper Left Counting Chamber; LR- Lower Right Counting Chamber; LL- Lower Left Counting Chamber; LR- Lower Right Counting Chamber. PER- Percentage of sperm concentration; LD RATIOLive Death Ratio.

\subsubsection{Effect of the Extract on Sperm Motility}

Table 4. Shows a dose dependent effect of Ethanolic extract of Icacinia manni on sperm motility.

\begin{tabular}{lll}
\hline Group & Motility Rate \% & Sperm Quality \\
\hline A & 80 & Large population of normal sperm cells present. \\
B & 70 & Some dead sperm cells with head abnormalies were present \\
C & $<60$ & Abnormal sperm cells \\
D & 20 & Majority were immotile sperm cells with head abnormalities \\
\hline
\end{tabular}

Marked reduction in sperm motility was seen with high dose administration.

Head abnormalities also increased with increased dose of exposure.

\section{Sperm Motility Comparison}

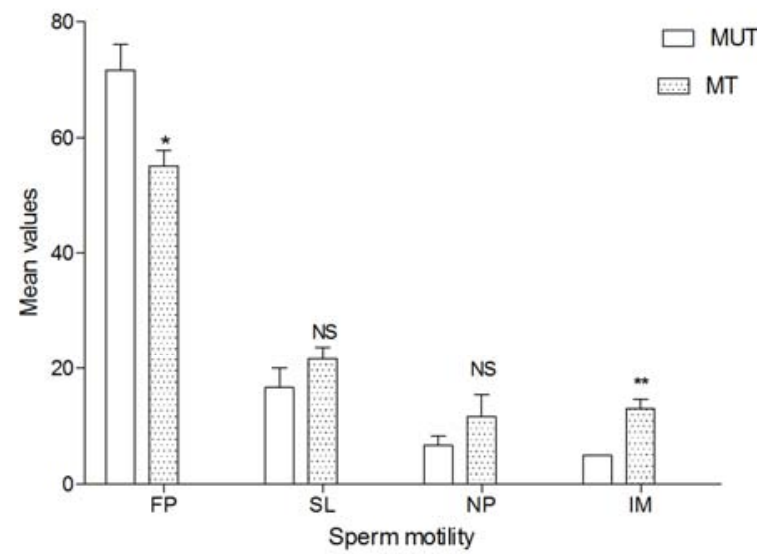

Figure 2. Comparison of Mean Sperm Motility of Male untreated (MUT) and Male treated (MT).

Key:

MUT- Male Untreated group

MT- Male Treated group

NS not significantly different from untreated at $5 \%(\mathrm{p}>0.05)$ *significantly different from untreated at $5 \%(\mathrm{p}<0.05),{ }^{* *}$ significantly different from untreated at $1 \%(\mathrm{p}<0.01)$.

\section{Fast Progressive Sperm (FP)}

The Mean Fast Progressive Sperm was computed to be $71.67 \pm 4.41$ and $55.00 \pm 2.89$ for male untreated and male treated respectively. The mean FP for male untreated was significantly higher than that of the male treated at $5 \%$ $(\mathrm{t}=3.16, \mathrm{p}=0.034, \mathrm{p}<0.05)$.

Slow Progressive Sperm (SL)

The Mean Slow Progressive Sperm for the male treated $(21.67 \pm 2.08)$ was not significantly higher than that of the male untreated $(16.67 \pm 3.33)$ at $5 \% \quad(\mathrm{t}=1.282, \mathrm{p}=0.269$, $\mathrm{p}>0.05$ ).

No Progressive Movement (NP)

The mean \pm SEM None Progressive Sperm of $6.67 \pm 1.67$ and $11.67 \pm 3.76$ were obtained for the untreated and treated males respectively. Although, that of the male treated was higher than that of the untreated male but it was not significantly at $5 \%(t=1.22, \mathrm{p}=0.291, \mathrm{p}>0.05)$.

Immotile Sperm (IM)

The mean Immotile Sperm in male treated $(13.00 \pm 1.67)$ was significantly higher than male untreated $(5.00 \pm 000)$ at $1 \%(\mathrm{t}=5.00, \mathrm{p}=0.007, \mathrm{p}<0.01)$.

\subsubsection{Mean Sperm Morphology Comparison}

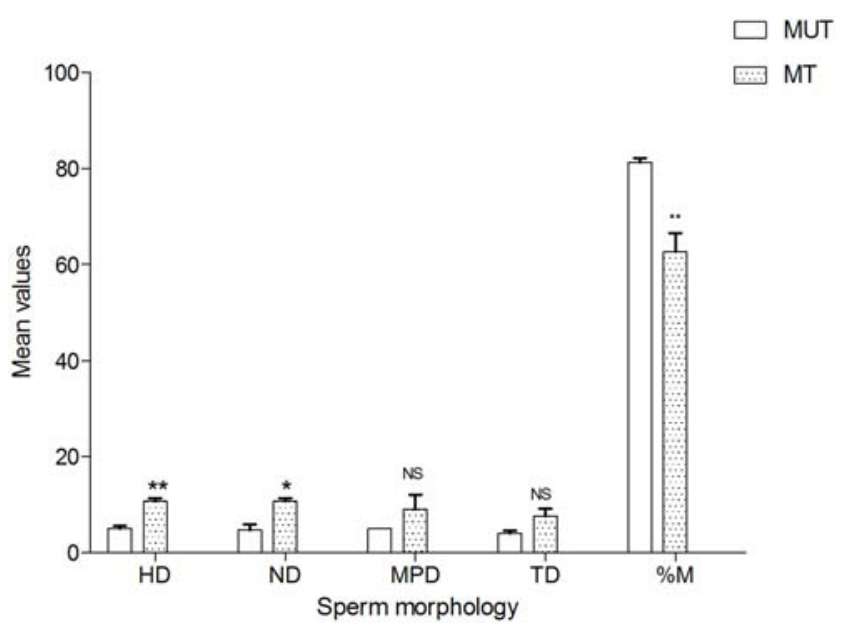

Figure 3. Comparison of mean sperm morphology of Male untreated (MUT) and Male treated (MT).

Key:

MUT- Male Untreated group

MT- Male Treated group

NS-not significantly different from untreated at $5 \%(\mathrm{p}>0.05) *$ significantly different from untreated at $5 \%(\mathrm{p}<0.050),{ }^{* *}$ significantly different from untreated at $1 \%(\mathrm{p}<0.01)$. 


\section{Head Defect (HD)}

The mean Head Defect in male treated $(10.67 \pm 0.67)$ was significantly higher than that of male untreated $(5.00 \pm 0.58)$ at $1 \%(\mathrm{t}=6.43, \mathrm{p}=0.003, \mathrm{p}<0.01)$.

Neck Defect (ND)

The mean \pm SEM Neck Defect values of $4.67 \pm 1.20$ and $10.67 \pm 0.67$ were obtained for male untreated and male treated respectively. The mean ND in male treated was significantly higher than male untreated at $5 \% \quad(\mathrm{t}=4.37$, $\mathrm{p}=3.06)$ at $5 \%(\mathrm{t}=1.31, \mathrm{p}=0.26, \mathrm{p}>0.05)$.

Mid Piece Defect (MDP)

There was no significantly difference in the mean Mid Piece Defect between male untreated $(5.00 \pm 0.00)$ and male treated $(9.00 \pm 3.06)$ at $5 \%(\mathrm{t}=1.31, \mathrm{p}=0.261, \mathrm{p}>0.05)$.

Tail Defect (TD)

The mean Tail Defect in male untreated $(4.00 \pm 0.58)$ was not significantly less than that of the male treated $(7.67 \pm 1.45)$ at $5 \%(\mathrm{t}=2.35, \mathrm{p}=0.079, \mathrm{p}>0.05)$.

Percentage of normal Morphology $(\% \mathrm{M})$

The meanPercentage of normal Morphology values of $81.33 \pm 0.88$ and $62.67 \pm 3.84$ were obtained for male untreated and male treated respectively. The mean $\% \mathrm{M}$ in male treated was significantly less than that of the untreated males at $1 \%$ $(\mathrm{t}=4.73, \mathrm{p}=0.009, \mathrm{p}<0.01)$

\subsubsection{Sperm Concentration Comparison}

Upper Right Counting Chamber (UR)

The mean concentration of sperm in the Upper Right Counting Chamberin male untreated $(16.00 \pm 0.58)$ was not significantly different from male treated $(13.33 \pm 1.76)$ at $5 \%$ $(\mathrm{t}=1.44, \mathrm{p}=0.224, \mathrm{p}>0.05)$.

Upper Left Counting Chamber (UL)

The mean concentration of sperm in the Upper Left Counting Chamber in male treated $(12.67 \pm 0.88)$ was marginally less than that of the untreated $(15.33 \pm 1.86)$ at $5 \%$ $(\mathrm{t}=1.30, \mathrm{p}=0.264, \mathrm{p}>0.05)$.

Lower Right Counting Chamber (LR)

The male treated reported a significant less mean concentration of sperm in the Lower Right Counting
Chamber $(14.00 \pm 2.08)$ than male untreated $(20.67 \pm 0.88)$ at $5 \%(\mathrm{t}=2.95, \mathrm{p}=0.042, \mathrm{p}<0.05)$.

Lower Left Counting Chamber (LL)

The mean concentration of sperm in the Lower Left Counting Chamber in male treated $(19.33 \pm 0.33)$ was significantly higher than male untreated $(17.67 \pm 0.33)$ at $5 \%$ $(\mathrm{t}=3.54, \mathrm{p}=0.024, \mathrm{p}<0.05)$.

Percentage of Sperm Concentration (PER)

The mean Percentage of Sperm Concentration in male untreated $(69.67 \pm 3.82)$ was not significantly different from that of male treated $(59.33 \pm 3.48)$ at $5 \%(\mathrm{t}=2.16, \mathrm{p}=0.097$, $\mathrm{p}>0.05)$.

\section{LD (Live Death) RATIO}

The mean Live Death Ratio of male treated $(58.33 \pm 1.67)$ was significantly less than that of the male untreated $(73.33 \pm 1.67)$ at $1 \%(t=1.36, p=0.003, p<0.01)$.

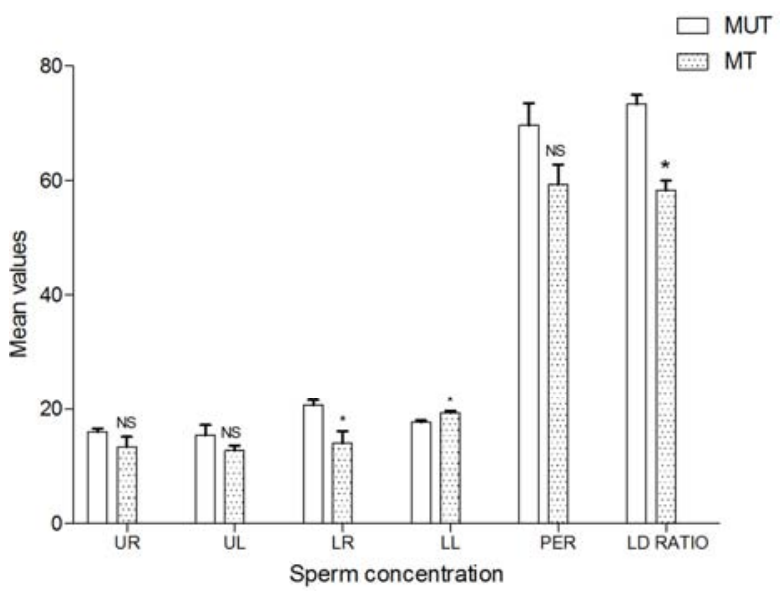

Figure 4. Comparison of mean Sperm Concentration of Male untreated (MUT) and Male treated (MT).

Key:

MUT- Male Untreated group

MT- Male Treated group

NS not significantly different from untreated at $5 \%(\mathrm{p}>0.05) *$ significantly different from untreated at $5 \%(\mathrm{p}<0.050)$, ${ }^{* *}$ significantly different from untreated at $1 \%(\mathrm{p}<0.01)$.

\subsection{Testicular Histology}

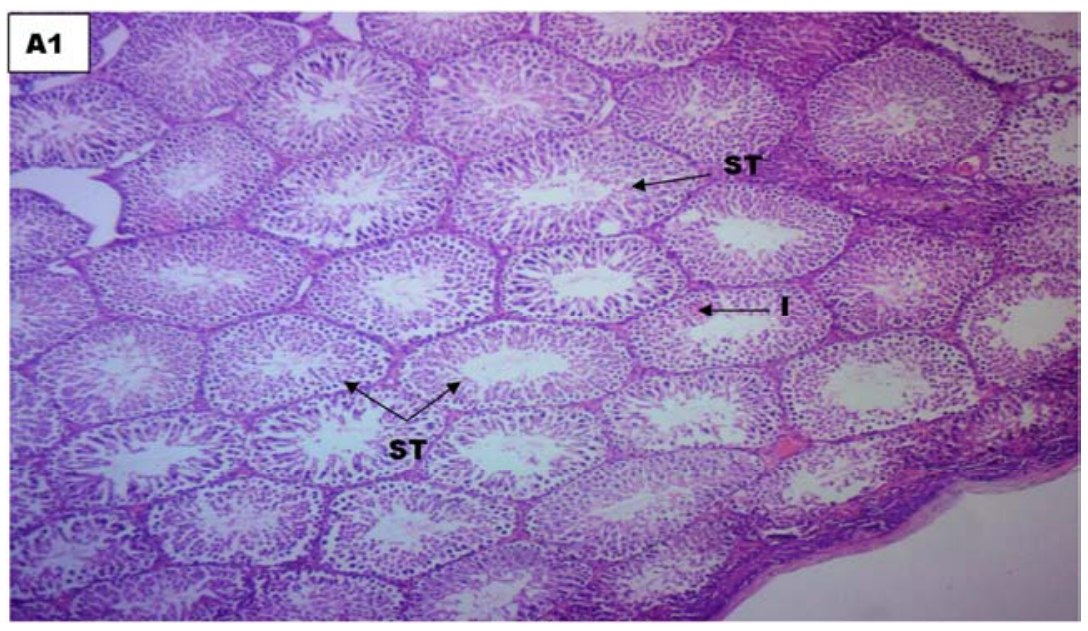




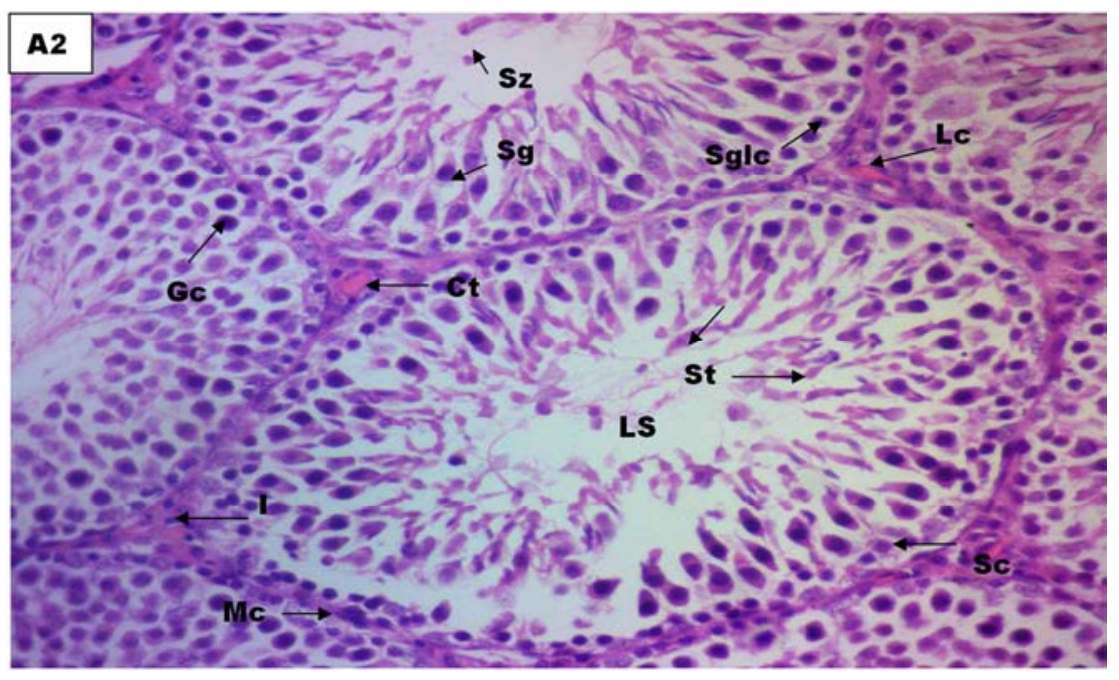

Figure 5. Photomicrographs of Testes of Rat without treatment (group A, control) stained with $H \&$ E method at Mag. A1(X100) \& A2(X400).

Keys: Seminiferous Luminal Tubules (ST), Germinal cells (Gc), Interstitium (I), Spermatogenic lining cells (Sglc), Myoid cells (Mc), Spermatocytes (Sp), Spermatids (St), Spertolic cells (Sc), Leydyg cells (LC) and Connective Tissue (Ct)
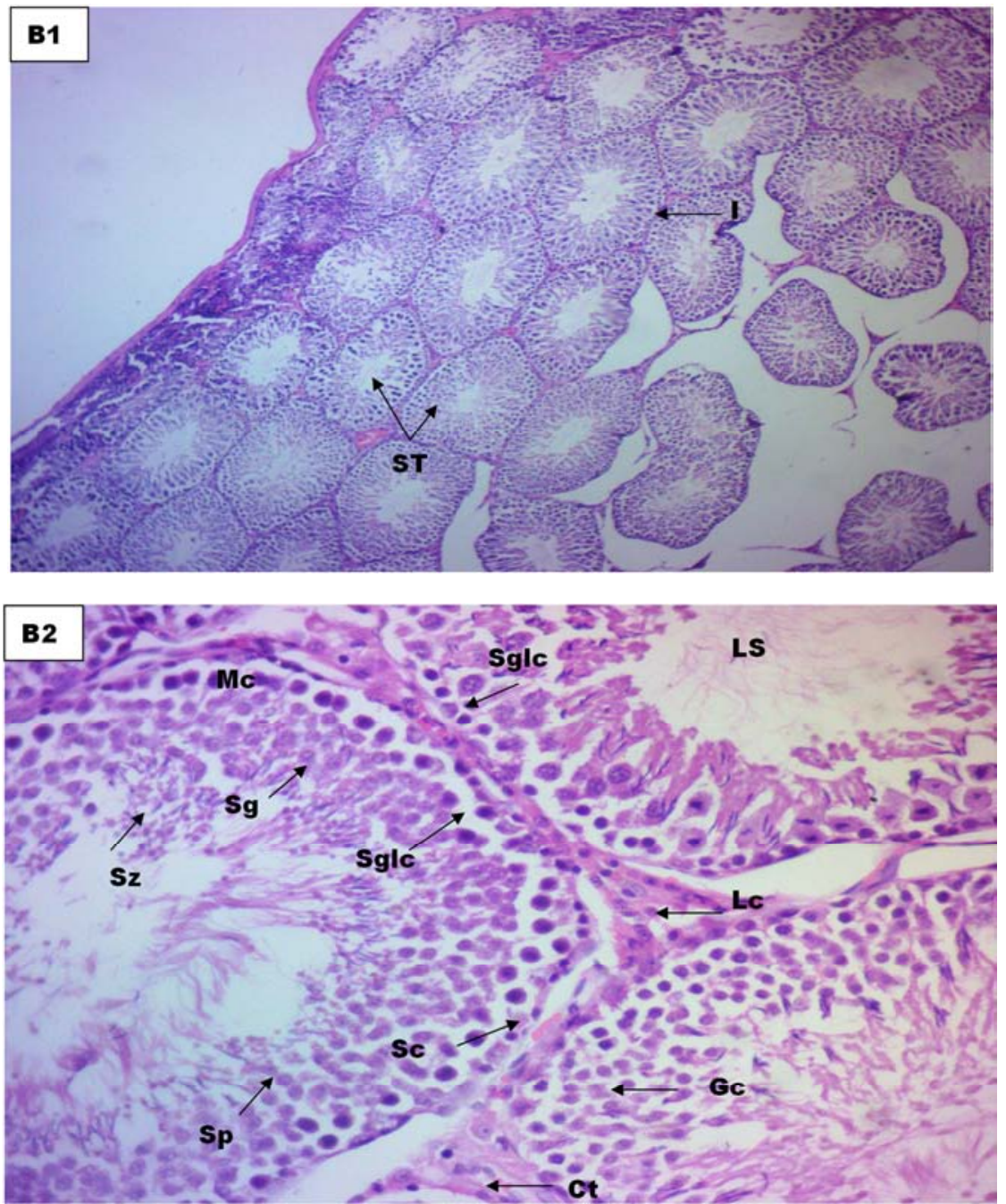

Figure 6. Photomicrographs of Testes of Rat treated with $89.44 \mathrm{mg} / \mathrm{kgethanolic} \mathrm{extract} \mathrm{of} \mathrm{Icaciniamanni} \mathrm{tuber} \mathrm{(group} \mathrm{B)} \mathrm{stained} \mathrm{with} H$ \& E method at Mag. $B 1(X 100) \& B 2(X 400)$.

Keys: Seminiferous Luminal Tubules (ST), Germinal cells (Gc), Interstitium (I), Spermatogenic lining cells (Sglc), Myoid cells (Mc), Spermatocytes (Sp), Spermatids (St), Spertolic cells (Sc), Leydyg cells (LC) and Connective Tissue (Ct) 

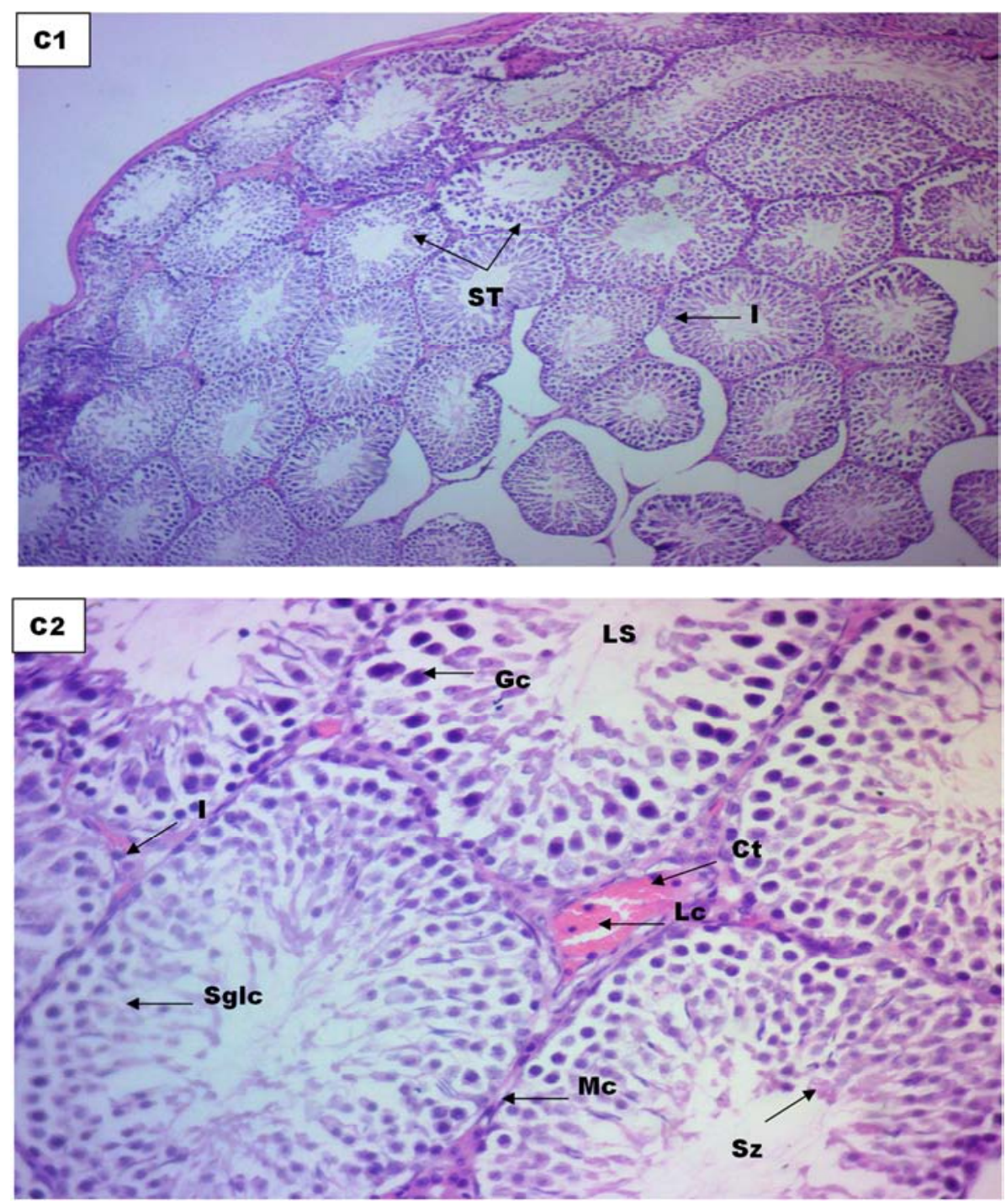

Figure 7. Photomicrographs of Testes of Rat treated with 178.88mg/kgethanolic extract of Icaciniamanni tuber (group C) stained with $H$ \& E method at Mag. $C 1(X 100) \& C 2(X 400)$.

Keys: Seminiferous Luminal Tubules (ST), Germinal cells (Gc), Interstitium (I), Spermatogenic lining cells (Sglc), Myoid cells (Mc), Spermatocytes (Sp), Spermatids (St), Spertolic cells (Sc), Leydyg cells (LC) and Connective Tissue (Ct)

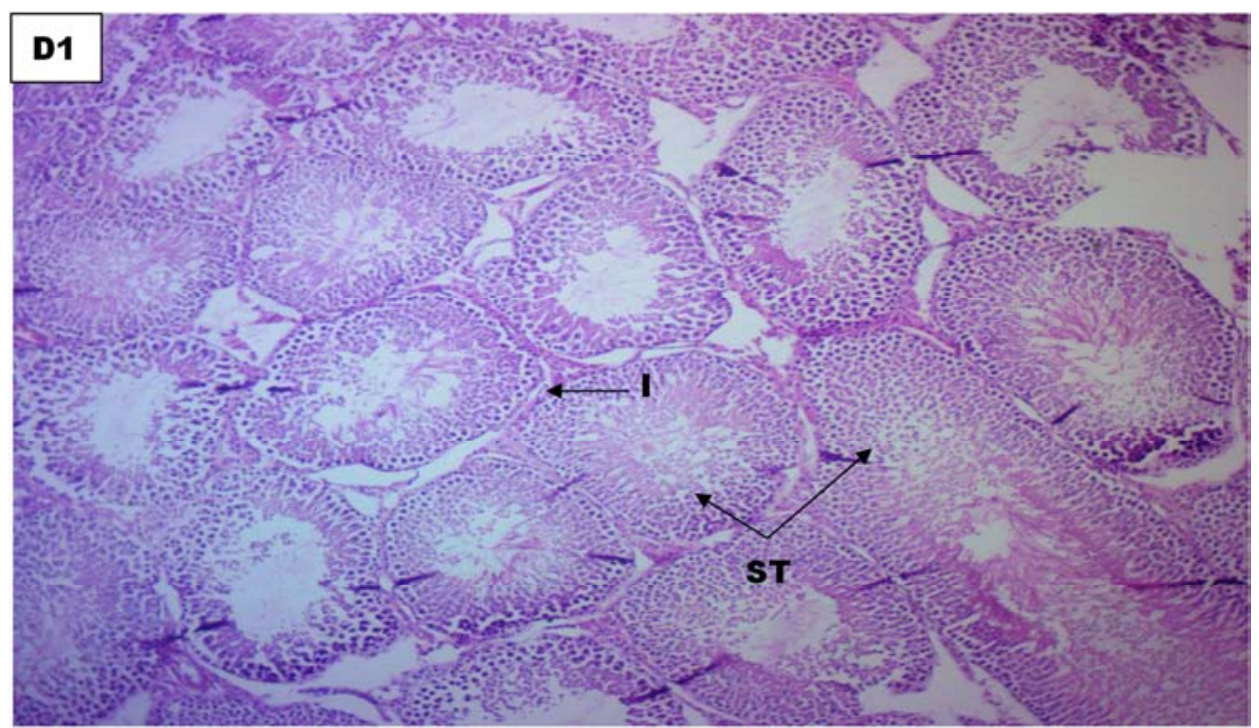




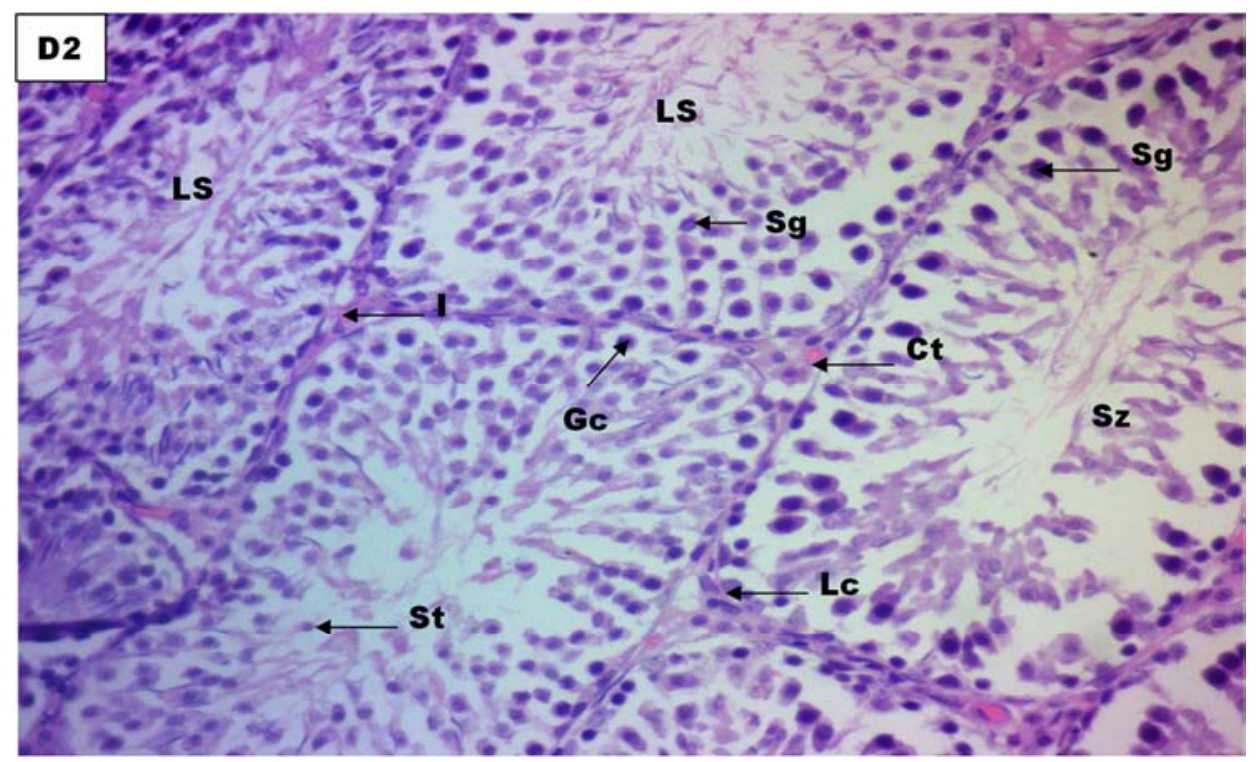

Figure 8. Photomicrographs of Testes of Rat treated with268.32mg/kgethanolic extract of Icaciniamanni tuber (group D) stained with $H$ \& E method at Mag. $D 1(X 100) \& D 2(X 400)$.

Keys: Seminiferous Luminal Tubules (ST), Germinal cells (Gc), Interstitium (I), Spermatogenic lining cells (Sglc), Myoid cells (Mc), Spermatocytes (Sp), Spermatids (St), Spertolic cells (Sc), Leydyg cells (LC) and Connective Tissue (Ct)

Group A, Control (Figure 5): Histologic section of the Testes without treatment at magnification $\mathrm{A} 1(\mathrm{x} 100)$ and A2(x400) revealed normal cellular profile of semiferoustubles, sertolic cells, spermatogenic lining cells, leydyg cells, germcells, lining myoid cells, spermatonia, spermatocytes and spermatids all within normal cellular archicteture without ay form of abnormality.

Conclusion: Not affected

Group B , Treated with 89.44mg/Kg (Figure 6): Histologic section of the Testesat magnification B1(x100) and B2(x400) revealed hypochromic section of seminiferous tubules with swollen germinal cells and spermatogenic lining cell and irregular alignment of myoid cells when compared to control group.

Conclusion: Moderately affected

Group C , Treated with 178.88mg/kg (Figure 7): Histologic section of the Testes at magnification C1 (x100) and C2 (x400) revealed hypochromic section seminiferous tubules with swollen germinal cells and spermatogenic lining cell and irregular alignment of myoid cells when compared to control group

Conclusion: Moderately affected

Group D, Treated with $268.32 \mathrm{mg} / \mathrm{Kg}$ (Figure 8): HistologicsectionofTestes at Magnification D1(X100) \& $\mathrm{D} 2(\mathrm{X} 400)$ show numerous atrophied and damaged seminiferous tubules, degenerated myoid cells, spermatogenic lining cells, spermatogonia, spermatocytes, spermatids, spermatozoa and lumen filled with semen, degenerated interstitial cells of leydig and interstitium against background of connective tissues with marked area of necrosis as compared to the control group.

Conclusion: Highly affected

\section{Discussion}

Nutrition, as one process in which the body so depends on for energy and other nutrients is also one the most susceptible means by which the body gets exposed to toxic substances. In most cases, these exposures are usually through intake of contaminated foods. But in some other cases, the body is exposed to naturally occurring toxins in plant used as foods. Exposure to toxins either by food intake or any other means always result in one health issue or another. It becomes more threatening as most people who are exposed to these toxins are unaware and preventive measures are not considered.

In this current study, the effects of intake of Icacinia manni tuber on reproductive health were accessed in male rats. As established earlier, this plant tuber contains many phytochemicals which include hydrogen cyanide, alkaloids, phytic acid, oxalic acid and tannins. These toxins have been shown to cause negative impacts on the body system.

Reproductive health is interwoven with other body system. It works synergistically with other systems especially the endocrine system for proper functioning. Disruption in any system, organ, tissue and even cellular functions which are linked to it will impede its central function which aimed at childbirth.

The testicular histology of the rats treated with Icacinia manni has shown severe damage in this study. Numerous atrophied and damaged seminiferous tubules, degenerated myoid cells, spermatogenic lining cells, spermatogonia, spermatocytes, spermatids and spermatozoa were observed. Lumen filled with semen, degenerated interstitial cells of leydig and interstitium against background of connective tissues with marked area of necrosis as compared to the untreated group. It has been observed that almost all the non 
nutritional compounds of Icacinia manni have some apoptotic and oxidative stress tendencies. Mills et al. [11] discovered that cyanide induces apoptosis and oxidative stress on differentiated PC12 cells. Akaloids has also been shown to exhibit apoptotic tendency as observed by Leeet al. [12] in hepatocellular Carcinoma Cells. This possibly being the reason for the suggestion of its use in cancer treatment. Also, a study on Soy-bean in which phytate and saponins are among the non-nutritional contents was observed to show apoptotic property on the intestinal mucosa cells in young rats. In this study, the atrophied and necrotic damage on the testis as observed in the histology confirms the apoptotic effects of Icacinia manni tuber.

The danger of any drug, chemical or substance that can penetrate the brain cannot be overemphasized. Reasons being that, damage to the brain cells could likely be considered as damage to the whole body since it controls the body activities. Icacinia manni tuber has been observed in this study to disrupt the hypothalamic-pituitary axis in the deviation in gonadatropin levels in the untreated group from the untreated groups. Three possible reasons can be deduced; interfering with the synthesis of GHRH in the hypothalamus, desensitization of the GHRH receptors on the ganadotropes, or interfering with the synthesis of gonadotropins itself. Umoren et al. [1] in 2007 had observed decreased feeding in chicken whose feed was made of Icacainia manni. This also suggests its effect on the feeding centre in the hypothalamus.

Though, steriodogenesis occurs in other organs, the male gonad becomes the chief site when gonadotropins are considered. Though other factors may contribute, but the degeneration of the leydig cells of the testis as observed in the histology should be assumed as the main cause of the decrease testosterone and progesterone. Estradiol was not significantly affected and this should be as a result of its secretion from adrenal gland and other organs.

The non-nutritional component of Icacinia manni tubers has been shown to impair the metabolism of some trace minerals which are important in cell functions in which hormones synthesis and release is a part. In a review by Delimont et al. [13], it has been shown that tannin affects iron absorption and causes reduction in its bioavailability. Other reports have also shown that oxalate and phytate impair the absorption of iron, zinc and calcium [14, 15] and Schlemmer et. al. [16] added that this may promote mineral deficiencies. Gallo-Payet and Payet confirms that calcium is also important for maximal steroidogenesis [17].

Mitochondria are essential sites for steroid hormone biosynthesis. Cells mostly use iron in mitochondria for the synthesis of haem and ISCs (iron-sulfur clusters e.g ferredoxin reductase and ferredoxin) [18]. Ferredoxin reductase and ferredoxin are generic electron transfer protein for cholesterol side-chain cleavage enzyme, P450scc. This enzyme system converts cholesterol to pregnenolone and determines net steroidogenic capacity, so that it serves as the chronic regulator of steroidogenesis. The main action of cyanide is an impairment of the ability of tissues to utilize oxygen through inhibition of cytochrome-c oxidase, which ultimately blocks adenosine triphosphate (ATP) synthesis which occurs in the mitochondria [19]. This means that Cyanide may interfere with steriodogenesis in as much as it interferes with ATP generation which is the source of energy for cellular activities and which also occur in the mitochondria.

Spermatogenesis occurs in the seminiferous tubules of the testis and testosterone produced by the leydig cells plays a central role. The testicular histology of this study has shown severe damage to the parts. Therefore, the decrease testosterone, together with the damage on the seminiferous tubules would collectively produce the defect on the sperm parameters as observed in this study.

The morphological damage on the sperm is a result of the interference of the Icacinia manni compounds with spermatogenesis or by their oxidative stress induced damage. A marked defect on the head and neck regions of the sperm was observed in this study. Defect in the head region of the sperm is usually considered as acrosome and chromatin anomalies [20]. Clinically, it has been noted that globozoospermic men cases lack the ability to activate the oocyte [21], thus leading to fertilization failure [20]. This possibly shows that these rats may have difficulty to achieve pregnancy.

Decrease sperm concentration also observed possibly due the apoptotic property of the compounds affecting spermatogenesis and steriodogenesis.

In the case of sperm motility, which is highly affected by this plant tuber, it could also be traced back to the effect of its compounds on energy production, specifically hydrogen cyanide. Cellular processes such as motility, capacitation, hyperactivation and the acrosome reactionuse adenosine triphosphate (ATP) as energy source [22, 23]. As noted earlier, hydrogen cyanide interferes with this process and probably is the reason for the very high decrease in sperm motility in this study. The morphological defects of the sperm cells especially at the neck, mid-piece and the tail region could possibly be one of the primary contributing factors as defective sperm morphology in these regions greatly affects its motility.

Generally, the effect of Icacinia manni tuber on the reproductive parameters as observed in rats in this study is very detrimental. Asuquo and Udedibie [24], had observed decrease in the number of eggs laid and Haugh unit, albumen and yolk indices being badly depressed by Icacinia manni meal in laying hens. This ofcourse projects the antifertiltity effect of this plant tuber as observed in this study.

\section{Conclusion}

The exposure to the phytochemicals in Icacinia manni tuber as observed in this study is detrimental to reproductive health. This exposure could be by direct consumption or by consuming meats from animals fed with it. In both cases, these effects could possibly have impact in the next generation, thus making it more debilitating.

The consumption of Icacinia manni tuber has affected 
almost all aspects of male reproductive system. These deteriorating effects were observed to affect spermatogenesis, steriodogenesis, hypothalamic-pituitary-gonadal axis and histology of the testis. The seminalysis result also confirms severe damage to sperm and this will possibly affect its function.

Therefore based on these findings, the use of Icacinia manni tubers should be avoided while more researches on it effects and possible ways to reduce these effects be an area for intense work for researchers.

\section{References}

[1] Umoren, U. E., Isika, M. A., Asanga, E. P. and Ezeigwe, P. N. (2007). Effect of Replacement of Maize with Earth Ball (Icacinia manni) Meal on the Performance of Broiler Chickens. Pakistan Journal of Biological Sciences, 10: 23682373.

[2] Fassiet, D. W. (1973). Oxalates: Intoxicants Occurring Naturally in Foods. National Academy of Science, Washington DC.

[3] Antai, S. P. and Obong, U.S. (1992). The effects of fermentation on the nutrient status of some toxic components of Icacinia manni. Plant Foods for Human Nutrition, 42: 219224.

[4] Essien, C. A. and Sam, I. M. (2018). Nutritional Evaluation of Icacinia manni (Earth Ball) Processed in Saline as a Source of Dietary Energy in Broiler Production. Journal of Biology, Agriculture and Healthcare, 8 (20).

[5] Antai, S. P. \& Nkwelang, G. (1999). Reduction of some toxicants in Icacina mannii by fermentation with Saccharomyces cerevisiae. Plant foods for human nutrition (Dordrecht, Netherlands). 53: 103-111.

[6] Burkil. H. M. (1985). The Useful Plants of West Tropical Africa. Royal Botanic Gardens; Kew.

[7] Malan, D. F., Neuba, D. F. R. and Kouakou, K. L. (2015). Medicinal plants and traditional healing practices in ehotile people, around the aby lagoon (eastern littoral of Côte d'Ivoire). Journal of Ethnobiology and Ethnomedicine, 11 (21).

[8] Lorke, D. (1983). A new approach to practical acute toxicity testing. Archives of Toxicology. 54: 275-287.

[9] Rouge, M. (2004). Sperm morphology. In M. Rouge (ed.), Hypertexts for biomedical sciences. Colorado: Colorado State University Press, 33-36.

[10] Zaneveld, L. J. D. and Polakoski, K. L. (1977). Collection and physical examination of the ejaculate. In E. S. E. Hafez (Ed.), Techniques of human andrology. Armsterdam: North Holland Biomedical Press, 147-156.

[11] Mills, E. M., Gunasekar, P. G. and Pavlakovic, G. and Isom,
G. E. (1996). Cyanide-induced apoptosis and oxidative stress in differentiated PC12 cells. Journal of Neurochemistry, 67 (3): 1039-1046.

[12] Lee, H., Baek, S. H., Lee, J. H., Kim, C., Ko, J., Lee, S., Chinnathambi, A., Alharbi, S. A., Yang, W. M., Um, J., Sethi, G., and Ahn, K. S. (2017). Isorhynchophylline, a Potent Plant Alkaloid, Induces Apoptotic and Anti-Metastatic Effects in Human Hepatocellular Carcinoma Cells through the Modulation of Diverse Cell Signaling Cascades. International Journal of Molecular Sciences, 18: 1095.

[13] Delimont, N. M., Haub, M. D. and Lindshield, B. L. (2017). The Impact of Tannin Consumption on Iron Bioavailability and Status: A Narrative Review. Current Developments in Nutrition, 1 (2): 1-12.

[14] Lopez, H. W., Leenhardt, F., Coudray, C. and Remesy, C. (2002), Minerals and phytic acid interactions: is it a real problem for human nutrition? International Journal of Food Science \& Technology, 37: 727-739.

[15] Zimmermann, M. B. and Hurrell, R. F. (2007). Nutritional iron deficiency in patients with chronic illnesses. Lancet, 370 (9586): 511-520.

[16] Schlemmer, U., Frølich, W., Prieto, R. M. and Grases, F. (2009). Phytate in foods and significance for humans: food sources, intake, processing, bioavailability, protective role and analysis. Molecular Nutrition \& Food Research, 53 (2): S330375 .

[17] Gallo-Payet, N. and Payet, M. D. (1989). Excitation-secretion coupling: involvement of potassium channels in ACTHstimulated rat adrenocortical cells. Journal of Endocrinology. 120: 409-421.

[18] Wang, J., \& Pantopoulos, K. (2011). Regulation of cellular iron metabolism. The Biochemical journal, 434 (3): 365-381.

[19] Cummings, T. F. (2004). The treatment of cyanide poisoning. Occupational Medicine (Oxford University Press journal) 54: $82-85$.

[20] Franken, D. R. and Henkel, R. (2012). Morphopathology of Sperm: It's Impact on Fertilization Journal of Reproduction and Stem Cell Biotechnology, 3 (1): 1-8.

[21] Chemes, H. E. andRawe, V. (2007). Sperm pathology: pathogenic mechanisms and fertility potential in assisted reproduction in Male Infertility: Diagnosis and treatment edsOehninger SC and Kruger TF InformaLkd, UK, 85-103.

[22] Mannowetz, N., Wandernoth, P. M. and Wennemuth, G. (2012). Glucose is a pH-dependent motor for sperm beat frequency during early activation. PLoS One 7: e41030.

[23] Mukai, C. and Travis, A. J. (2012). What sperm can teach us about energy production. Reproduction in Domestic Animals, 47 (4): 164-169.

[24] Asuquo, L. E. and Udedibie, A. B. I. (2012). Effects of Dietary Toasted Icacinia manni Meal on the Performance of Laying Hens. International Journal of Agriculture and Rural Development. 15 (3): 1162-1168. 